\title{
EVOLUTION OF FOLATE CONTENT DURING WORT PRODUCTION
}

\author{
D. KOREN*, B. HEGYESNÉ VeCSERI and G. Kun-FARKAS \\ Department of Brewing and Distilling, Faculty of Food Science, Szent István University, \\ H-1118 Budapest, Ménesi út 45. Hungary
}

There are numerous scientific publications about the folate content of several types of beers available in commercial trade, but there is limited information about the effect of raw materials and technological steps of brewing on folate content. In this study the aim was to investigate different raw materials and the evolution of folate content during laboratory and pilot scale brewing. For the determination of folate content of different malts, three types of barley malts (Pilsner, Caramel, and Coloring), wheat malt, rye malt, and oat malt were analysed. For the study of the evolution of folate content during the brewing process, worts were produced on laboratory and pilot scale. Among malts, Pilsner type barley malt had the highest folate content $(44.7 \mu \mathrm{g} / 100 \mathrm{~g} \mathrm{~d} . \mathrm{m}$.). During brewing the protein rest seemed to dissolve the majority of the folate content, and with the increasing temperature of the $\beta$ - and $\alpha$-amylase rests there was a further dissolution. Filtration and sparging did not have negative effect on folate concentration related to the extract content of the wort. Hop boiling had no negative effect on folate content, folate seemed to be stable during the one-hour boiling. Natural folate of barley malt seemed to be stable through the technological steps of brewing, offering the possibility to produce a foodstuff with high natural folate content.

Keywords: folate, malts, brewing, mashing, filtration, hop boiling

There are numerous scientific publications about the folate content of several types of beers available in commercial trade, in these it has been reported that beer can be a valuable source of folate depending on beer type, but a huge deviation is observed between the different products. There is lack of information about the effect of raw materials and technological steps of brewing on folate content that could be helpful to understand the evolution of folate during the brewing process and to get a deeper insight into what makes the folate content of each product so different.

Folate belongs to the vitamin B family. It serves as an essential coenzyme in one carbon metabolism, principally as acceptor and donor of one-carbon units. Through this role, folate coenzymes mediate the metabolism of nucleic and amino acids, and thus fill an important function in purine and pyrimidine metabolism and the remethylation of homocysteine to methionine. Methionine is the immediate precursor of S-adenosyl methionine, which functions as the universal donor in many transmethylation reactions, including the methylation of DNA, histones, and other proteins. Thus, folate deficiency can lead to severe metabolic and clinical consequences (PITKIN, 2007; MolL \& DAVIS, 2017).

Folate occurs in natural foods as several vitamers, reduced derivatives of folic acid (pteroyl-L-glutamic acid), which mainly exist as polyglutamates. Folic acid, which is a monoglutamate, is the oxidised and most active form of the vitamin found rarely in food, it is the form used in vitamin preparations and food fortification (ANDERSSON et al., 2008).

\footnotetext{
* To whom correspondence should be addressed.

Phone: +36305548402; e-mail: danikoren3@gmail.com
} 
Methods to quantify folates in food samples are complicated due to the numerous forms of native folates, their instability, the complexity and variety of food matrices, and the relatively low concentration of the analytes (ARCOT \& SHRESTHA, 2005). In this study the microbiological assay was applied, because it is suitable for the determination of total folate content, does not require sophisticated instrumentation, is relatively economical, and has high sensitivity (PFEIFFER et al., 2010).

There are several publications about the folate content of beers originating from different countries of the world. Póo-Prieto and co-workers (2011) investigated the folate content of Spanish beers, which ranged between 1.6 and $2.6 \mu \mathrm{g} / 100 \mathrm{ml}$. WALKER and co-workers (2003) reported values for total folate in Bavarian wheat beers ranging from 4.7 to $12.5 \mu \mathrm{g} / 100 \mathrm{ml}$. PIETERCELIE and co-workers (2003) claimed that $14 \%$ of refermented Belgian beers contained more than $20 \mu \mathrm{g} / 100 \mathrm{ml}$, while BERTUZZI and co-workers (2020) reported the folate content of 80 beers (40 small-scale, 40 large-scale) available in Italy ranging between 1.55 and 10.48 $\mu \mathrm{g} / 100 \mathrm{ml}$. Based on these results, it is hard to draw conclusions about the general folate content of beer, but the study of brewing technology can help to understand the differences.

The folate content of beer originates from two main sources: grains and yeasts. As more than $90 \%$ of commercial beers are filtered, the grain is the primary source of folate in the majority of the final products. The most often used cereal for beer brewing is barley, but wheat, oat, and rye are also applied besides barley. Grains used for brewing are mainly used in their malted form. The malting process consists of three main stages: steeping, germination, and kilning. Germination has been reported as a way to improve folate content in wheat (KoeHLER et al., 2007), barley (WALKER et al., 2002), oats (WILHELMSON et al., 2001), and rye (LiUKKONEN et al., 2003).

Beer brewing is a biotechnological process during which, with the help of the enzymes of malted cereals (mainly barley), the micro and macro nutrients of the malt are dissolved in water (mashing), then separated from the water insoluble particles (wort separation, filtration), boiled with hops (hop boiling), then the precipitated protein-polyphenol complexes and hop residues are separated in the whirlpool, afterwards the liquid (hopped wort) is cooled down and inoculated with brewer's yeast. In this research the effect of mashing, wort separation, hop boiling, and whirlpool were studied.

There is only one publication about the study of the folate content during some technological steps of brewing, as mashing, fermentation, and packaging, in pilot and commercial scale breweries (JÄGERSTAD et al., 2005). But this article does not provide any information about the technological parameters (temperature, time, volume, facilities, and so on), furthermore does not provide concrete concentrations of folate content, it reports the results in the dimension of folate content relative to barley. In order to draw concrete conclusions, it is necessary to know the technological parameters and facilities accurately. In this study the aim was to investigate different raw materials and the evolution of folate content in laboratory and pilot scale brewing with the detailed description of the technological parameters.

\section{Materials and methods}

\subsection{Malt samples}

For the investigation of folate content of different malts, three types of barley malts (Pilsner, Caramel, and Coloring), wheat malt, rye malt, and oat malt were analysed. 


\subsection{Samples during the brewing technology}

For the study of the evolution of folate content during the brewing process, worts were produced with different equipment in different volumes. On laboratory scale, wort was produced with infusion technology, and the effect of an extended protein rest was also tested. On pilot scale, the same infusion technology was applied as on laboratory scale, but was carried out on a 501 capacity pilot brewery consisting of a mash tun, lauter tun, boiling kettle, and whirlpool. For all the brewing experiments $100 \%$ Pilsner malt was used.

1.2.1. Laboratory scale samples. The mashing on laboratory scale was carried out in a 1-CUBE mashing bath (1- CUBE s.r.o., Czech Republic).

The brewing technology under laboratory conditions was as follows: mashing-in was carried out at $52{ }^{\circ} \mathrm{C}$ with a water:malt ratio of $4: 1$ (300 ml water and $75 \mathrm{~g}$ malt), then the temperature of the mash was kept at $52{ }^{\circ} \mathrm{C}$ for $20 \mathrm{~min}$ (protein rest), that was followed by a 45 min rest at $62{ }^{\circ} \mathrm{C}\left(\beta\right.$-amylase rest), and finally there was a 15 min rest at $72{ }^{\circ} \mathrm{C}(\alpha$-amylase rest). At the beginning of the $\alpha$-amylase rest, $100 \mathrm{ml}$ water was added to the mash to substitute the sparging step on laboratory scale. The temperature between the enzymatic rests was raised by $1{ }^{\circ} \mathrm{C} \mathrm{min}{ }^{-1}$. The filtration was carried out using Whatman MN-615 filter paper (GE Healthcare). The hop boiling lasted for $60 \mathrm{~min}$ in Erlenmeyer flask, at the $5^{\text {th }}$ min $0.72 \mathrm{~g}$ Hallertau Tradition hops (10\% a-acid) were added. Samples for analysis were taken at the end of all enzymatic rests during mashing, after filtration, and after hop boiling. The samples were immediately cooled below $10{ }^{\circ} \mathrm{C}$ to stop all enzymatic processes, centrifuged at 10000 r.p.m., and put in the freezer until analysis.

For the investigation of the effect of an extended protein rest, the same 1-CUBE mashing bath was used. The mashing-in temperature was $52^{\circ} \mathrm{C}$ and the water:malt ratio was $4: 1$. The mash was kept for $40 \mathrm{~min}$ at $52{ }^{\circ} \mathrm{C}$ and samples were taken every $10 \mathrm{~min}$. The samples were taken and stored the same way as in case of laboratory scale brewing.

1.2.2. Pilot scale samples. The pilot scale brewing was carried out in a 501 capacity brewing equipment with steam heating. The mashing-in was carried out in a mashing tun at $52{ }^{\circ} \mathrm{C}$ with a water:malt ratio of 3:1 (30 liter water and $10 \mathrm{~kg}$ malt), then the temperature of the mash was kept at $52{ }^{\circ} \mathrm{C}$ for $20 \mathrm{~min}$ (protein rest), that was followed by a 45 min rest at 62 ${ }^{\circ} \mathrm{C}$ ( $\beta$-amylase rest), and finally there was a $15 \mathrm{~min}$ rest at $72{ }^{\circ} \mathrm{C}(\alpha$-amylase rest), then the temperature was raised to $78^{\circ} \mathrm{C}$ prior to mashing-out. The temperature between the enzymatic rests was raised by $1{ }^{\circ} \mathrm{C} \mathrm{min}^{-1}$. After the mashing, the mash was transferred to the lauter tun, which was followed by a 20 min sedimentation rest. Then the first wort was separated and sparged two times. The hop boiling of the sweet wort lasted for $60 \mathrm{~min}$, at the $5^{\text {th }} \mathrm{min} 30 \mathrm{~g}$ Hallertau Tradition hops were added. Then the hopped wort was pumped into the whirlpool, where the hot trub was separated. Samples were taken at the end of all enzymatic rests during mashing, after first wort separation, from each sparging, from the sweet wort before hop boiling (first wort +2 sparging together), and after whirlpool. The samples were taken and stored the same way as in the case of laboratory scale brewing.

\subsection{Determination of folate content}

For the determination of total folate content, a microbiological microtiter plate from R-Biopharm AG (Darmstadt, Germany) was used (AOAC-RI - 100903). The procedure was the following: exactly $1 \mathrm{~g}$ grinded sample and $20 \mathrm{mg}$ pig pancreatin was weighed into a 50 
$\mathrm{ml}$ centrifuge vial, then $40 \mathrm{ml}$ phosphate buffer ( $0.05 \mathrm{~mol}$ ascorbate, $\mathrm{pH} 7.2)$ was added and shaken. It was incubated for $2 \mathrm{~h}$ at $37^{\circ} \mathrm{C}$ in the dark and shaken 5 times during the incubation. Thereafter, the extract was heated for $30 \mathrm{~min}$ at $95{ }^{\circ} \mathrm{C}$ in a water bath, chilled down quickly to below $30{ }^{\circ} \mathrm{C}$, and centrifuged at $8000 \times g$ for $5 \mathrm{~min}$. Finally, $150 \mu \mathrm{l}$ folic acid assay medium and $150 \mu \mathrm{l}$ standard or diluted sample was pipetted into the cells covered by Lactobacillus rhamnosus. It was incubated at $37{ }^{\circ} \mathrm{C}$ in the dark for $48 \mathrm{~h}$, and optical density was measured at $\lambda=600 \mathrm{~nm}$. The measurement was carried out in three parallels.

\subsection{Determination of extract content}

The real extract content was determined by an Anton-Paar DMA 4500 beer analyser.

\subsection{Determination of moisture content}

The moisture content of the malts was determined by an AND MX-50 Moisture Analyzer.

\section{Results and discussion}

\subsection{Folate content of malts}

The folate contents of the malts produced from different grains are given in $\mu \mathrm{g} / 100 \mathrm{~g}$ related to dry matter (d.m.). As it can be seen in Figure 1, there are magnitude differences between the different types of barley malts. Pilsner type barley malt, which is an enzyme rich pale malt, kilned at $80-85^{\circ} \mathrm{C}$, had the highest folate content (44.7 $\mu \mathrm{g} / 100 \mathrm{~g} \mathrm{~d}$.m.). Caramel malt, which is usually used to give amber-brownish colour and caramel like taste to beer, had a folate content of $5.5 \mu \mathrm{g} / 100 \mathrm{~g} \mathrm{~d} . \mathrm{m}$. due to the high temperature $\left(140-180{ }^{\circ} \mathrm{C}\right)$, as this type of malt is roasted to caramelise the sugars in the endosperm. Colouring malt does not contain any folate as it is roasted above $200{ }^{\circ} \mathrm{C}$, at which temperature folate is completely degraded.

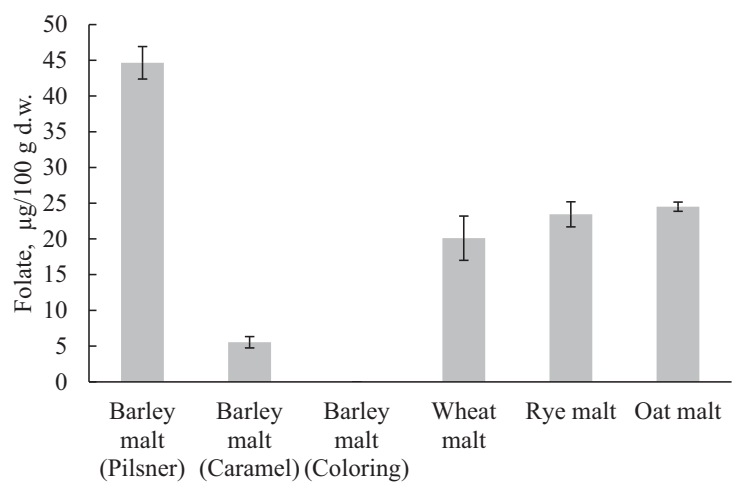

Fig. 1. Folate content of malts (mean, sd, n=3)

Wheat, rye, and oat malts have similar folate contents, 20.1, 23.4, and $24.5 \mu \mathrm{g} / 100 \mathrm{~g}$ d.m., respectively. These results are due to the lack of husk in the case of wheat and rye, as the outer layers and the husk are richer sources of folate than the endosperm of the kernels (EDELMANN et al., 2013). In the case of oats, the kernel has a large husk, but despite this, 
based on our results, the folate content is not higher in oat malt than in wheat or rye malts. This result agrees with the observation of EDELMANN and co-workers (2012), who reported a lower folate concentration in oats than in rye and barley, but slightly higher than in wheat. Based on these results Pilsner malt was selected as the raw material for the brewing experiments.

\subsection{Evolution of folate content during extended protease rest}

As folate accumulates mainly in the outer layers of the kernel and occurs in polyglutamate form (GIORDANO et al., 2016), an experiment was carried out by the extension of the protease rest to see if it has any effect on the liberation of folate. The mash was kept at $52{ }^{\circ} \mathrm{C}$ for 40 min and samples were taken every $10 \mathrm{~min}$. The results show (Fig. 2) no effect of the extended rest on folate content. It is maybe due to the fact that malts available nowadays are very well modified and rich in enzymes. Thanks to this, the liberation of folate and its dissolution in water is done in $10 \mathrm{~min}$.

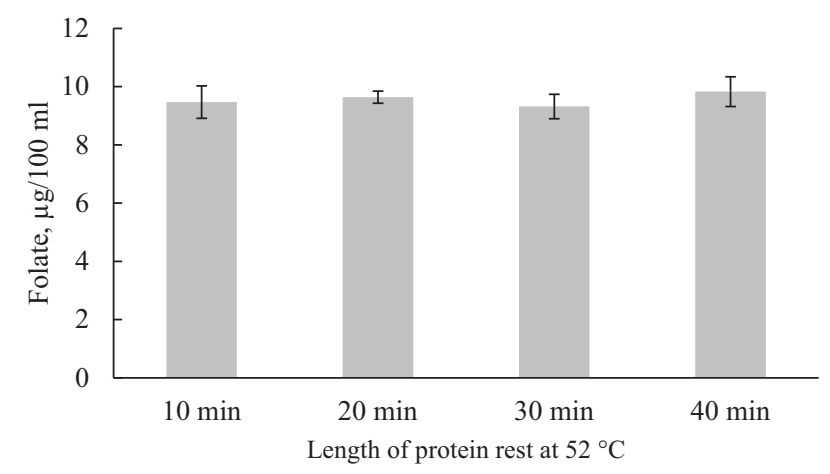

Fig. 2. Evolution of folate content during an extended protein rest (mean, sd, n=3)

\subsection{Evolution of folate content during laboratory scale brewing}

The results of the brewing on laboratory scale are presented in Figure 3. After the protein rest, the folate content is similar to the results of the extended protein rest. Further increase can be observed after the $\beta$-amylase rest at $62{ }^{\circ} \mathrm{C}$. This can be due to the gelatinisation of the starch that is between $60-63{ }^{\circ} \mathrm{C}$ in the case of barley malt (PATINDOL et al., 2012). The gelatinisation can help further liberation of folate structurally bound. At the end of the $\alpha$-amylase rest, there is a decrease, which can be explained by the dilution of the mash, as $100 \mathrm{ml}$ water was added when reaching $72{ }^{\circ} \mathrm{C}$ to substitute the sparging step. Filtration through filter paper, the next technological step after mashing, does not have any influence on folate content. On the other hand, hop boiling seems to have a significant effect on it, but it must be taken into account that during hop boiling due to evaporation of water, the extract content increases, which affects the concentration of folate. To eliminate this, the folate content of the first wort and hopped wort was calculated related to $12 \% \mathrm{~m} / \mathrm{m}$ extract content (Table 1 ). The results related to extract content show no difference in folate content of the first wort and hopped wort produced on laboratory scale. It means that despite of the one hour boiling, folate does not degrade, it seems to be stable at this temperature for this period of time. 


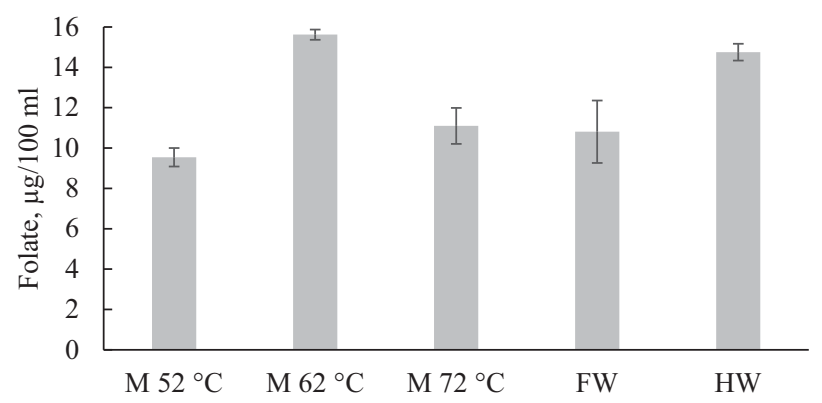

Fig. 3. Evolution of folate content during laboratory scale brewing (mean, sd, $\mathrm{n}=3$ ). $\mathrm{M} 52{ }^{\circ} \mathrm{C}$ : end of $52{ }^{\circ} \mathrm{C}$ enzymatic rest; $\mathrm{M} 62{ }^{\circ} \mathrm{C}$ : end of $62{ }^{\circ} \mathrm{C}$ enzymatic rest; $\mathrm{M} 72{ }^{\circ} \mathrm{C}$ : end of $72{ }^{\circ} \mathrm{C}$ enzymatic rest; $\mathrm{FW}$ : first wort; HW: hopped wort

Table 1. Extract content and folate content of samples taken during the brewing process

\begin{tabular}{llcc}
\hline & Sample name & Extract content $(\% \mathrm{~m} / \mathrm{m})$ & Folate content* $(\mu \mathrm{g} / 100 \mathrm{ml})$ \\
\hline Laboratory scale & First wort (FW) & 11.78 & $11.0 \pm 1.5$ \\
& Hopped wort (HW) & 15.53 & $11.4 \pm 0.3$ \\
Pilot scale & First wort (FW) & 16.54 & $12.5 \pm 0.1$ \\
& Sparging 1 (S1) & 7.11 & $10.4 \pm 0.5$ \\
& Sparging 2 (S2) & 3.01 & $14.7 \pm 1.9$ \\
& Before hop boiling (BHB) & 10.74 & $11.4 \pm 0.7$ \\
& Hopped wort (HW) & 11.33 & $10.6 \pm 1.9$ \\
\hline
\end{tabular}

* related to $12 \% \mathrm{~m} / \mathrm{m}$ extract $(\operatorname{mean} \pm \mathrm{sd}, \mathrm{n}=3)$

\subsection{Evolution of folate content during pilot scale brewing}

In the case of pilot scale brewing, an increasing tendency can be observed during mashing (Fig. 4). The difference between the sample taken at the end of the protein rest in laboratory and in the pilot brewery is due to the different water:malt ratio for mashing-in; in the laboratory it is $4: 1$, while in the pilot brewery it is $3: 1$. This different mashing-in ratio is needed because of the different conditions of filtering. In laboratory the mash is filtered through filter paper and there is no possibility of sparging, so the mash should be thinner, while in the brewery the filtration takes place in a lauter tun, where sparging can be carried out resulting in the dilution of the wort, so the mash should be thicker. After the filtration the folate concentration decreases from 19.6 to $17.2 \mu \mathrm{g} / 100 \mathrm{ml}$, and in the case of the two sparging a further decrease is observed. These results were also calculated related to $12 \%$ $\mathrm{m} / \mathrm{m}$ extract content (Table 1 ), which shows that the folate content related to extract content of the first sparging is lower than that of the first wort, while the folate content of the second sparging is higher. The sample taken before hop boiling, which contains the first wort +2 spargings, shows that related to extract content, the two sparging together only slightly decreased the folate content of the first wort. Hop boiling was gentler in the pilot brewery, which resulted in less evaporation and less extract difference between the start and end of the boiling. The folate content does not show any remarkable change during boiling either in the case of normal results or in the case the results calculated related to extract content. It can be 
stated that hop boiling, which could be considered to have negative effect on folate content of beer does not decrease the concentration either on laboratory or on pilot scale.

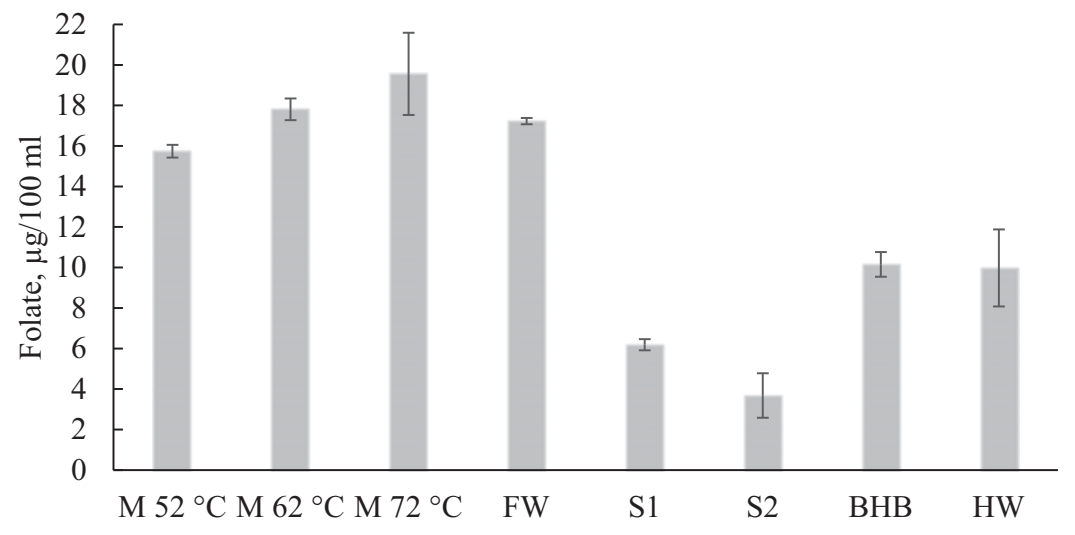

Fig. 4. Evolution of folate content during pilot scale brewing (mean, sd, n=3). $\mathrm{M} 52{ }^{\circ} \mathrm{C}$ : end of $52{ }^{\circ} \mathrm{C}$ enzymatic rest; M $62{ }^{\circ} \mathrm{C}$ : end of $62{ }^{\circ} \mathrm{C}$ enzymatic rest; $\mathrm{M} 72{ }^{\circ} \mathrm{C}$ : end of $72{ }^{\circ} \mathrm{C}$ enzymatic rest; FW: first wort; S1: first sparging; S2: second sparging; BHB: before hop boiling; HW: hopped wort

\section{Conclusions}

As conclusion, it can be stated that during the protein rest of mashing, the majority of the folate content already goes into solution, but with the increase of temperature to the $\beta$ - and $\alpha$-amylase rests there is a further minor dissolution of folate. Filtration and sparging do not have negative effect on folate concentration related to the extract content of the wort. An unexpected but the most interesting result was observed during hop boiling, showing that the one-hour boiling does not have negative effect on folate content. Natural folate of barley malt seems to be stable against the technological steps of brewing, offering the possibility to produce a foodstuff with high natural folate content.

This research project was supported by the Doctoral School of Food Sciences of Szent István University (SZIU).

\section{References}

Andersson, A.A., Lampi, A.M., Nyström, L., Pitronen, V., Li, L., ... \& Fras, A. (2008): Phytochemical and dietary fiber components in barley varieties in the healthgrain diversity screen. J. Agr. Food Chem., 56(21), 97679776.

Arcot, J. \& Shrestha, A. (2005): Folate: Methods of analysis. Trends Food Sci. Tech., 16(6-7), 253-266.

Bertuzzi, T., Mulazzi, A., Rastelli, S., Donadini, G., Rossi, F. \& Spigno, G. (2020): Targeted healthy compounds in small and large-scale brewed beers. Food Chem., 310, 125935.

Edelmann, M., Kariluoto, S., Nyström, L. \& Pirronen, V. (2012): Folate in oats and its milling fractions. Food Chem., 135(3), 1938-1947.

Edelmann, M., Kariluoto, S., Nyström, L. \& Piironen, V. (2013): Folate in barley grain and fractions. J. Cereal Sci., 58(1), 37-44. 
Giordano, D., Reyneri, A. \& Blandino, M. (2016): Folate distribution in barley (Hordeum vulgare L.), common wheat (Triticum aestivum L.) and durum wheat (Triticum turgidum durum Desf.) pearled fractions. J. Sci. Food Agr., 96(5), 1709-1715.

Jägerstad, M., Piironen, V., Walker, C., Ros, G., Carnovale, E., Holasova, M. \& Nau, H. (2005): Increasing natural food folates through bioprocessing and biotechnology. Trends Food Sci. Tech., 16(6-7), 298-306.

Koehler, P., Hartmann, G., Wieser, H. \& Rychlik, M. (2007): Changes of folates, dietary fiber, and proteins in wheat as affected by germination. J. Agr. Food Chem., 55(12), 4678-4683.

Liukkonen, K.H., Katina, K., Wilhelmsson, A., Myllymaki, O., Lampi, A.M., ... \& Peltoketo, A. (2003): Process-induced changes on bioactive compounds in whole grain rye. P. Nutr. Soc., 62(1), 117-122.

Moll, R. \& Davis, B. (2017): Iron, vitamin B12 and folate. Medicine, 45(4), 198-203.

Patindol, J., Mendez-Montealvo, G. \& Wang, Y.J. (2012): Starch properties of malted barley in relation to real degree of fermentation. Starch-Stärke, 64(7), 517-523.

Pfeiffer, C.M., FAzili, Z. \& Zhang, M. (2010): Folate analytical methodology. -in: Bailey, B.L. (Ed.), Folate in health and disease. CRC Press (Taylor \& Francis Group, LLC), Boca Raton, Forida, USA, pp. 517-574.

Pietercelie, A., Michaux, V., Brevard, M.A. \& Debourg, A. (2003): Refermented beers: An interesting source of folate. Proceedings of the European Brewery Convention Congress, IRL Press, Oxford, Dublin, Ireland, pp. 1366-1374.

PitKIn, R.M. (2007): Folate and neural tube defects. Am. J. Clin. Nutr., 85(1), 285S-288S.

Póo-Prieto, R., Alonso-Aperte, E. \& Varela-Moreiras, G. (2011): Analysis of folate form distribution in Spanish beers using combined affinity and ion-pair chromatography. J. Inst. Brew., 117(2), 188-194.

Walker, C.J., Amblar, S. \& Patel, D. (2002): Die Auswirkung des Brauprozesses auf Folsäure-(Vitamin B9)Gehalt im Bier. Brauwelt, 11, 350-356.

WAlker, C.J., Smith, R. \& Livens, S. (2003): The folate (vitamin B9) content of commercially available malted products and co-products. -in: WALKER, C.J.: The folate content of malted products: Strategies for improvement. HGCA Project Report 321, pp. 11-22.

Wilhelmson, A., Oksman-Caldentey, K.M., Laitila, A., Suortti, T., Kaukovirta-Norja, A. \& Poutanen, K. (2001): Development of a germination process for producing high $\beta$-glucan, whole grain food ingredients from oat. Cereal Chem., 78(6), 715-720.

Open Access statement. This is an open-access article distributed under the terms of the Creative Commons Attribution 4.0 International License (https://creativecommons.org/licenses/by/4.0/), which permits unrestricted use, distribution, and reproduction in any medium, provided the original author and source are credited, a link to the CC License is provided, and changes - if any - are indicated. (SID_1) 